\title{
Share Repurchases: A Literature Review
}

\author{
Mr. Sarthak Kumar Jena (Corresponding author) \\ Vinod Gupta School of Management, Indian Institute of Technology \\ Kharagpur-721302, India \\ E-mail: srkjena@gmail.com \\ Dr. Chandra Sekhar Mishra \\ Associate professor in Accounting and Finance \\ Vinod Gupta School of Management, Indian Institute of Technology \\ Kharagpur-721302, India
}

Tel: (Office): +91-3222-282318Ｅ-mail: csmishra@vgsom.iitkgp.ernet.in

\author{
Dr. Prabina Rajib \\ Professor in Accounting and Finance \\ Vinod Gupta School of Management, Indian Institute of Technology \\ Kharagpur-721302, India \\ Tel: (Office): +91-3222-283886 E-mail: prabina@vgsom.iitkgp.ernet.in
}

Received: June 20, 2016 Accepted: August 10, $2016 \quad$ Published: December 1, 2016

doi:10.5296/ajfa.v8i2.9759 URL: http://dx.doi.org/10.5296/ajfa.v8i2.9759

\begin{abstract}
Share repurchases evolved as an alternative method of payout and a corporate finance tool in 1950 in the USA. From 1980 to 2000 it has achieved a significant growth as compared to dividend payment by companies. Then, share repurchase is gradually spread to other countries like UK, Canada, etc. Pertinent to its growing importance, over the years an enormous literature has emerged that deals with many facets of share repurchase. This article classifies and organizes literature in relations to the established hypotheses, determinants affecting share repurchase decisions, the effect of share repurchase on liquidity and earning management around share repurchase. In additions to the above, this article also analyses the
\end{abstract}




\section{Macrothink}

Asian Journal of Finance \& Accounting ISSN 1946-052X 2016, Vol. 8, No. 2

regulatory framework of Indian buyback starting from 1998. It gives a brief view of sections of old Companies Act (1956) and new Companies Act (2013) dealing with buyback. This article also provides a snapshot of SEBI buyback regulations, 1998 and also accommodates all the amendments.

Keywords: Share buyback, Determinants, Liquidity, Earnings management, SEBI Buyback Regulations (1998), Companies Act 2013. 


\section{Introduction}

Share repurchase or buyback of shares means companies purchase their shares from the shareholders. It is an investment technique used by the companies to invest in their shares. Repurchased shares may be either cancelled or kept in treasury for further issue depending on the country's rules and regulation. Firms have to extinguish the repurchased shares in countries like India, Australia, Sweden, France, Canada and UK. In countries like the US and Spain, the companies keep the repurchased shares in treasury for reissue. In Italy, companies can either extinguish the shares or held as treasury stock for reselling.

Share repurchases ${ }^{1}$ are similar to a dividend on the distribution of cash to the shareholders. However, the dividend is pervasive in the sense; companies have been paying regular cash dividend since the inception of joint stock companies around three hundredyears ago. Initially, it is the only method of payment of surplus to the stakeholders. Miller and Modigliani, (1961) first-time proposes that the value of companies remains same before and after dividend payment. So dividend payment is considered as a puzzle in corporate finance. Before 1980, companies preferred dividend as a favorite method of payout despite the relative tax advantage of repurchase (Barclay and Smith, 1988). But after 1980 the growth of repurchase has been tremendous in the US. Repurchase as expenditure increased from $4.8 \%$ in 1980 to $41.8 \%$ in 2000. The average growth of repurchase is almost four times than the average growth in dividends. Share repurchase as a percentage of total dividend increased from $13.1 \%$ in 1980 to $113.1 \%$ in 2000 . In $1999-2000$ for the first time in US history companies spent more on repurchase than dividends (Grullion and Michaely, 2000). After this growth, many countries adopted share repurchase as an alternative method of payout. After the US, UK is the second most developed country where repurchase has gained popularity and then spread to countries like Canada, Australia, Japan, France, etc.

The rest of the paper is organized as follows. Section 2 provides a brief view of the rules and regulation relating to buyback in India. Section 3 discusses the hypotheses responsible for share buyback decisions. Section 4 discusses the Indian buyback scenario. Section 5 discusses the determinants of share repurchase. Section 6 discusses the impact of share repurchase on post-buyback market liquidity of the firm. Section 7 discusses the earnings management around share repurchase and Section 8 concludes the paper.

\section{Law regulating Share buyback in India}

The principal act responsible for share buyback in India is Companies Act 1956.In 1999 an amendment to the Companies Act allowed Indian companies to repurchase their shares with retrospective effect from October 1998. This enactment introduced three sections(77A,77AA $\& 77 \mathrm{~B})$ to the existing Companies Act to allow repurchase of shares. Before this amendment, the company is restricted to repurchase their shares under section 77 of Companies Act 1956.Companies are only allowed to repurchase their shares under section 100 and 402 of Companies Act 1956. Section 100 deals with capital reduction with due approval from a court not lower than high court. Section 402 allows companies to repurchase shares with the

\footnotetext{
${ }^{1}$ Share repurchase and share buyback are used interchangeably throughout the paper.
} 
permission from company law board (CLB) in a case of mismanagement or oppression. The new sections overrule the previous section such as sections like 100,402 and 77. Section 77A deals with rules and regulations relating to share buyback. Section 77AA deals in the transfer of certain sum to the capital redemption reserve account. When companies repurchase shares out of their free reserve, then a sum equal to the nominal value of shares is transferred to the capital redemption reserve account. Section 77B prohibits companies to buy their shares in certain circumstances. The details of Section 77A 77B are discussed below.

\subsection{Section $77 A$}

A company cannot repurchase its own shares unless it is authorized by the Articles of association. Companies have to pass only a board resolution if the share buyback is less than $10 \%$ of the paid up capital and free reserves but if it exceeds $10 \%$ then a special resolution in the general body meeting has to be passed by the shareholders. The maximum ceiling of buyback of shares is $25 \%$ of the paid up capital and free reserves. A company is not allowed to offer share buyback within a period of 365 days of the preceding offer. A company may purchase their shares out of the free reserve, securities premium, and proceeds of any shares and specified securities. No shares will be bought back from the proceeds of an earlier issue of the same kind of securities. Every share buyback shall be completed within 12 months from the passing of the special resolution. The company has to file a solvency report along with the resolution to the Registrar of companies and Securities Board of India (SEBI).The report is an assurance from the board of directors that it enquired about the financial condition of the company and found that the company is capable of meeting all its obligation and will not be insolvent within one year of the share repurchases. The report should be signed by at least two directors including managing director. Once the company repurchases its shares, then it cannot issue the same kind of shares within six months. Post-buyback, the debt of the company should not be more than twice of the capital and free reserves. Companies can buy back shares from the existing security-holders on a proportionate basis or from the open market operation or from odd lots or from the employees to whom shares are issued under the stock option plan. A Company has to extinguish the securities physically within seven days after the completion of the share buyback. A post buyback report has to be submitted to the Registrar of companies and SEBI within 30 days of the completion of the offer. If any company fails to comply with the rule and regulations of this section, then the officer-in-charge who is in default shall be punishable with imprisonment for maximum up to 2 years or a fine of 50000 or both.

\subsection{Section $77 B$}

A company is prohibited from repurchasing shares directly or indirectly through a subsidiary or an investment company. A company cannot repurchase shares if it is in default of payment of interest or dividend to debentures and preference share holder respectively. If a company is in default of interest payment to financial institutions then also it is debarred from buying its shares. 


\subsection{Companies Act 2013}

A new Companies Act came into existence in 2013 by scraping old Companies Act 1956.The rules and regulation relating share buyback are almost same in the new act except some minor changes. The new act contains share buyback provisions under sections 68, 69 and 70.The changes are as follows (i) The restriction period for share buyback is changed from 365 days to one year from the date of closure of the previous offer (ii) the period of share buyback is altered from 12 months to one year from the date of passing of the special resolution (iii) The fine amount for contravention of rules and regulations under companies Act is increased from fifty thousand to maximum 3lakh rupees and a minimum of 1lakh rupees. The imprisonment period is increased from maximum 2 years to 3 years.

\subsection{SEBI rules regarding share buyback}

Company's (amendment) Act, 1999 contains a clause that all companies whose shares are listed on any recognized stock exchange have to repurchase shares in accordance with the regulations made by Security Exchange Board of India (SEBI).Companies whose shares are listed on any stock exchange have to comply with both Companies Act and SEBI regulations. The first objective of SEBI since its inception in the year 1992, is to regulate the capital market and to make it more investor friendly. Another important objective of SEBI is to make the capital market more transparent and to match with international standard. So to fulfill the twin objectives of market development and investor protection it formulates various rules in all the concerned areas. SEBI for the first time prescribed rules regarding share buyback in the year 1998. It has been subsequently amended in the years 1999, 2001, 2004, 2006, 2007, 2008, 2012, and 2013.

\subsection{Securities and Exchange Board of India (Buy Back of Securities), Regulations, 1998}

SEBI for the first time introduced a comprehensive set of rules and regulations regarding share buyback in 1998 after Companies Act 1956 amended its provision related to repurchasing of shares by companies. The rules and regulations under this act are applicable to only those companies whose shares are listed on any stock exchange in India. A company cannot repurchase its shares for the purpose of delisting from the stock exchange. Share repurchases through tender offer, open market operation and from odd-lot holders are the three methods of share buyback in India. Companies are restricted to repurchase their shares through negotiated deals either on or off the stock exchange or through private arrangement. A special resolution passed in general body meeting and the resolution passed by the board of directors authorizing buyback should be filed with the SEBI and stock exchanges where the shares are listed within seven and two days of the passing of the resolution respectively.

\subsection{Securities and Exchange Board of India (Buy Back of Securities), Regulations, 1998}

The SEBI regulations 1998 prescribes the following rules to be followed for share buyback through tender offer. In share buyback through a tender offer, repurchase is made from the existing shareholders on a proportionate basis. This method reserves $15 \%$ of targeted shares (the number of shares likely to be bought back), or a number of securities entitled to small shareholders should be kept for them. The offer document should disclose the maximum 
price at which the shares will be repurchased. It should publish the information regarding the quantum of shares tendered by the promoters and detail of their transactions of last six months before passing the resolution, such as a number of shares acquired, price, and date of acquisition. The company has to make an announcement in public within two working days of passing of the resolution in at least one national English newspaper, one Hindi newspaper and a Regional language newspaper widely circulated in the area where the registered office of the company is located. A company has to submit a draft offer letter to the SEBI within five working days of the public announcement, and the board has to give its comment on the draft offer within seven working days of receiving the draft letter. Before the opening of buyback offer, every company shall announce a record date for identifying the legal shareholders who are entitled to participate in the offer. The letter of offer and a tender form shall be sent to the eligible shareholders within five working days of approval from SEBI. The date of opening of the offer is within five working days from the dispatch of the offer letter to the shareholders. The duration of the tender offer was initially not less than fifteen days and maximum thirty days, after the 2012 amendment it is reduced to ten working days. Every company going for share buyback has to open an escrow account and deposit $25 \%$ of the amount if the total consideration payable is not exceeding 100 cores. If the total consideration exceeds 100 cores, then $25 \%$ of up to 100 cores and $10 \%$ of the rest amount will be deposited. The escrow account consists of cash deposited in a scheduled commercial bank or bank guarantee in favor of merchant banker or a combination of both. On fulfillment of the entire obligation relating to share buyback offer the amount or guarantee kept in the escrow account will be released to the company. On non-compliance, SEBI forfeits the account fully or partly and distribute the amount to the tendering shareholders within seven working days of closure of the offer. All securities bought back in the offer shall be extinguished and physically destroyed in the presence of merchant banker, registrar to the issue and statutory auditor within seven days of completion of the share buyback. The company shall submit a certificate of compliance to the SEBI duly certified and authorized by the registrar, two directors of the company including managing director and statutory auditor within seven days of extinguishment of shares. A company also furnishes a report containing the particulars of the shares destroyed to the respective stock exchange where the shares were listed earlier.

\subsection{Share Buyback from the Open Market}

Companies can repurchase from the open market via two methods such as through stock exchange or book-building process. For any method under open market method, a company has to pass a special resolution in the general body meeting or board meeting of the directors. The maximum price per share is fixed in the special resolution but the price at which shares are bought depends on the market forces. Unlike tender offer, promoters and persons in control of the company are restricted to offer their share for sale in the process of open market share repurchase. Companies have to announce the repurchase at least seven days before the opening of the offer to the public. Such announcement has to be filed with SEBI within two days of the announcement. Share buyback under this method is only done through a stock exchange having a nation wide trading terminal. The company and the merchant 
banker shall furnish a daily report to the stock exchange on the shares bought back and published this information in a national newspaper on a fortnightly basis. Every time the company purchases additional five percent shares from the market, it has to be published in a national newspaper. The rule regarding cancellation or extinguishment of shares bought back is similar to tender offer.

The rules and regulations under share buyback through book-building are quite similar to share buyback through the stock exchange. The book-building process will be made through an electronically linked transparent facility. The number of bidding center should be not less than thirty including at least one electronically linked computer terminal at all the bidding center. The offer will remain open for not less than 15 days and not exceed 30 days. The highest price accepted for share buyback will be paid to all the holders whose shares are accepted. The public announcement must contain true, factual, and material information rather than misleading information. Directors must take the responsibility of the information published in the announcement. The consideration for share buyback must be paid in cash. The company cannot withdraw the offer after the draft letter of offer is filed with the SEBI or public announcement. The company will publish a report on share buyback such as a number of shares bought, the price at which shares are bought, the total amount invested and changes in the capital structure and shareholding pattern within two days of the completion of the offer in a national daily newspaper. All the subsequent amendments in the year 1999, 2001, 2004,2006,2007,2008, and 2012 are already inserted in the 1998 SEBI regulations Act except 2013 amendment.

\subsection{Share Buyback of Securities (Amendment) Regulations, 2013}

To make share buyback environment more transparent SEBI made certain changes in the rules of open market method of share buyback in the year 2013. These changes came into force on $8^{\text {th }}$ August 2013. Companies can share buyback maximum up to $15 \%$ of the capital and free reserves through the open market. If the companies want to exceed the limit specified in the amendment then, it should adopt tender offer route. No offer of share buyback shall be made within a year of completion of the previous share buyback. Initially, companies only make the public announcement for share repurchase without any intention of actually repurchasing shares. So in order to prevent such unethical practice, SEBI for the first time mandates at least $50 \%$ of the amount allotted towards share buyback in the special resolution must be utilized for buying back the shares. The public announcement shall be made within 7 working days after passing the resolution. The company has to file a copy of announcement to the SEBI simultaneously with the issue of the announcement by the company. Earlier the time limit for filing the copy with SEBI is within two days of such announcement. The company will furnish the daily data of share repurchase to the exchange in a format prescribed by it, and the stock exchange will upload the information to its official website immediately on a daily basis. Now the open market share buybacks commence not later than seven days after the public announcement and shall close within six months from the opening of the offer. Through this amendment, a new provision of the separate window is created by the stock exchange for buying of the securities in physical form. This window will remain open for all the share buyback period. Before the opening of the offer, the company 
will deposit $25 \%$ of the amount that likely to be invested in the share buyback (decided at the time of passing the resolution) in an escrow account. The minimum balance of the escrow account will be $2.5 \%$ of the amount kept for share buyback in the resolution. If SEBI found any irregularities in the process of the share buyback, then it forfeit the amount and then amount will be deposited in the investor protection and education fund of SEBI. The company cannot raise further capital for a period of one year from the closure of share buyback to expect in the discharge of its subsisting obligations.

\section{Indian Share buyback Environment}

As share buyback activity started lately in India, the only handful of research studies was carried on since the introduction of the share buyback. The previous research in India identifies many incentives for share repurchase such as: Signalling hypothesis (Reddy et al.,2013; Rajagopalan and Shankar, 2012), substitutes hypothesis (Hyderabad,2013),free cash flow hypothesis (Hyderabad, 2013), liquidity hypothesis (Arora,2012), share price performance (Chavali and Shemeem, 2011; Dua et al., 2010; Rajagopalan and Shankar, 2013) and on motivations of share buyback (Arora and Pasricha, 2012.

Table 1.Year wise number of share repurchases and values from 1998-2015

\begin{tabular}{|l|c|c|c|}
\hline Year & $\begin{array}{c}\text { No of share } \\
\text { repurchases }\end{array}$ & $\begin{array}{c}\text { Amount of share } \\
\text { repurchase } \\
\text { (Rs in Millions) }\end{array}$ & $\begin{array}{c}\text { Mean (\%) Share } \\
\text { repurchases }\end{array}$ \\
\hline $1998-99$ & 1 & 13.73 & 5.60 \\
\hline $1999-00$ & 12 & 249.80 & 19.29 \\
\hline $2000-01$ & 14 & 926.26 & 16.70 \\
\hline $2001-02$ & 27 & 797.82 & 13.01 \\
\hline $2002-03$ & 31 & 326.04 & 14.24 \\
\hline $2003-04$ & 8 & 64.66 & 17.52 \\
\hline $2004-05$ & 11 & 3272.52 & 29.71 \\
\hline $2005-06$ & 10 & 362.60 & 4.48 \\
\hline $2006-07$ & 7 & 421.78 & 4.77 \\
\hline $2007-08$ & 10 & 2004.44 & 5.19 \\
\hline $2008-09$ & 37 & 916.94 & 5.64 \\
\hline $2009-10$ & 20 & 411.99 & 8.80 \\
\hline $2010-11$ & 20 & 2147.51 & 8.99 \\
\hline $2011-12$ & 35 & 4440.46 & 7.16 \\
\hline $2012-13$ & 21 & 806.71 & 8.45 \\
\hline $2013-14$ & 32 & 3557.22 & 7.56 \\
\hline $2014-15$ & 9 & 605.21 & 14.05 \\
\hline Total & 305 & 21325.70 & \\
\hline & & & \\
\hline
\end{tabular}

Source: Authors own compilation.

In India, the option of share repurchase started on October 31, 1998, by Amendment of Companies Act 1956 and introduction of Securities and Exchange Board of India (Share 
buyback of Securities) Regulations 1998. Since 1998 till 2014, 219 companies have undertaken 305 share buybacks. India ranked fifteenth in the most active nation in share repurchase globally (Reddy et al., 2013). According to The Economic Times (2008), Reliance Energy's US\$ 885.9 million share buyback offer was the biggest corporate event in Asia during 2008-09. The year wise distribution of companies and the value of their repurchase are given in Table 1. Table 1 also shows the mean percentage of share buyback calculated as the number of shares offered for the share buyback to the number of outstanding shares in the previous year. It is quite evident from Table 1 that number of the share buyback is maximum (37) in the year 2008-09 and minimum (1) in the year 1998-99, the year when share buyback started in India. The value of share repurchase is maximum in the year 2011-12 (4440.46 million) and the value of share repurchase is lowest in the year 1998-99 (13.73 million).The mean percent of the share buyback is lowest in the year 2005-06 and highest in the year 2004-05. Table 2 shows the frequency of repurchase by Indian companies during the year from 1998-99 to 2014-15. Only 162 companies repurchased once, 39 companies purchased twice, 12 firms purchased thrice;two companies purchased fourth times ;three companies boughtfifth times and Selan Exploration topped the list by doing share buyback six times during this period.

Table 2. Frequency of share repurchases from 1998-2015

\begin{tabular}{|c|c|c|}
\hline Frequency of Share Repurchases & No of Companies & No of Share Repurchases \\
\hline Once & 162 & 162 \\
\hline Twice & 39 & 78 \\
\hline Thrice & 12 & 36 \\
\hline fourth & 2 & 8 \\
\hline Fifth & 3 & 15 \\
\hline Sixth & 1 & 6 \\
\hline Total & 219 & 305 \\
\hline
\end{tabular}

\section{Source: Authors own compilation.}

Table 3 shows the industry wise classification of total number share buybacks during the study period. The information technology industry topped the list by the maximum number of share buybacks (29) followed by pharmaceuticals industry (24). Pie chart 1 divides the total number of share buyback into three categories i.e. open market repurchase, tender offer, and book building. There is only two book building method of share repurchase till date from the starting of the share buyback. Mainly the Indian share buybacks are categorized as under two method i.e. stock exchange (220) and tender offer (83). In India companies going for share buyback are supposed to state one reason for the share buyback in the offer document. Pie chart 2 shows three different reasons i.e., returning of available cash, provide liquidity and exit option, stated by the Indian companies in the offer document. The dominant reason for share buyback in India is to return the available cash with the company to reduce the agency cost. The second important reason for the share buyback is to provide liquidity, as repurchase increases the trading of the shares during the offer period. The least stated reason for the share buyback is to give an opportunity to the investors to exit from the company. 


\section{Indian Share buyback Environment}

Share repurchase as a payout method exists in the US since 1950. But share repurchase as a tool of corporate finance gradually spread to the UK in 1980 and accepted worldwide during the 1990s. In this period, share repurchase started in France and Germany (1998), Japan (1995), Malaysia (1997), Singapore and Hong Kong (1998) and Taiwan (2000). But the significant surge in the repurchase activity started from 1980 to 2000. During these two decades, companies in the US spent more on repurchase than the dividend. This extraordinary growth of repurchase as a payout method has caught the attention of many researchers towards the cause and factors that motivate companies for repurchases. The extensive literature on share repurchase proposed many hypotheses, those drives companies for undertaking share buyback. The subsequent section discusess the hypotheses.

\subsection{Signaling Hypothesis}

As the company's management and ownership are in different hand, information possessed by the insider is higher than outsiders. So to maintain information symmetry or pass private information to outsiders many corporate decisions are taken such as dividend payment and share repurchase Signaling power of the dividend decisions is first pronounced by Ross (1977) and Bhattacharya (1979) by adopting Spence (1973) signaling model. Repurchase gives two types of signals such as undervaluation of shares of the company or about the future growth prospects of the company or both. When a company is announcing to buy-back shares at a huge premium, it gives a signal of undervaluation. Varmaelen (1981) found that signalling is the most prominent and plausible explanation for abnormal return after repurchase announcement. So it shows that repurchase conveys private information to the investors. The abnormal return after the tender offer is more than open market repurchase because tender offer provides more credible signal than open market share repurchase. In the case of a tender offer, the firm is more committed to doing share repurchase than open market share repurchase. Small firms announcing share repurchase through a tender offer, is consistent with the signalling hypothesis.

Bartov (1991) found that open market repurchase conveys information about both earnings and risk changes. So these firms enjoy unexpected annual earnings in the year of repurchase announcement. The repurchase announcement return is positively relatedtoearning and negatively relatedto systematic risk. According to Stephens and Weisbach (1998), there is a negative relationship between share repurchase and prior price performance of the stock. He found that firms increase their repurchase depending on the perceived undervaluation of their stock. Comment \& Jarrell (1991) examined three types of repurchases of shares such as Dutch auction self-tender offer, fixed price self-tender, and open market repurchase in the US to study the signalling effect of these methods and found that fixed price self- tender method conveys astrong signal of undervaluation than others. The study reported by Louis and White (2007) is consistent with Comment \& Jarrell (1991). Haw et al. (2013) examined the signalling effect of real repurchase and mimicking repurchase. The study found that long-term operating and market performance followed by the announcement of repurchase improves less for mimicking firms. 


\subsection{Excess Capital or Cash Flow Hypothesis}

Firms are having the excess capital or cash flow than the profitable investment opportunities likely to distribute the surplus cash to the shareholders to reduce the agency cost Jensen (1986).If firms are over flooded with cash or capital, there is a probability that firms may undertake negative net value projects. So higher payout reduces the free cash available at the discretion of the managers and also restricts the empire building desire of the managers. Vafeas and Joy (1995) reported empirical evidence supporting Jensen (1986). The study found that the announcement return arising around theannouncement of open market repurchases is the result of the reduction of agency cost. Boudry (2013) reported a positive relationship between the availability of cash and repurchase keeping invest opportunities constant. 
Table 3. Industry wise classification of share repurchases from 1998-2015

\begin{tabular}{|c|c|c|}
\hline Industry category & No. of companies & Percentage $(\%)$ \\
\hline Agro chemical & 2 & 0.64 \\
\hline Automobile & 13 & 4.18 \\
\hline Cables & 3 & 0.96 \\
\hline Carbone black & 3 & 0.96 \\
\hline Cement \& Construction Materials & 12 & 3.86 \\
\hline Chemicals & 12 & 3.86 \\
\hline Diamond Cutting \& Jewellery & 4 & 1.29 \\
\hline Diversified & 13 & 4.18 \\
\hline Electric Lamps \& Accessories & 21 & 6.75 \\
\hline Engineering & 5 & 1.61 \\
\hline Financial Services & 20 & 6.43 \\
\hline Food \& Food Processing & 7 & 2.25 \\
\hline Hotels \& Resorts & 3 & 0.96 \\
\hline Housing/ Civil Construction/ Real Estate & 5 & 1.61 \\
\hline Information Technology & 29 & 9.32 \\
\hline Machine Tools & 3 & 0.96 \\
\hline Oil Exploration/Drilling/Refining & 8 & 2.57 \\
\hline Packaging \&Plastic & 3 & 0.96 \\
\hline Paints/Varnishes & 5 & 1.61 \\
\hline Personal Care & 10 & 3.22 \\
\hline Petrochemicals & 2 & 0.64 \\
\hline Pharmaceuticals \& Drugs & 24 & 7.72 \\
\hline Plastics & 8 & 2.57 \\
\hline Power Generation \& Supply & 6 & 1.93 \\
\hline Project Contracting/ Machinery Manufacture & 7 & 2.25 \\
\hline Publishing & 6 & 1.93 \\
\hline Shipping (Repairing/ Breaking) & 3 & 0.96 \\
\hline Steel Tubes/Pipes/Wires & 12 & 3.86 \\
\hline Sugar Breweries \& Distilleries & 3 & 0.96 \\
\hline Tea/ Coffee & 4 & 1.29 \\
\hline Telecommunications & 16 & 5.14 \\
\hline Textiles & 15 & 4.82 \\
\hline Trading(Exports) & 6 & 1.93 \\
\hline others & 12 & 5.79 \\
\hline Total & 305 & 100 \\
\hline
\end{tabular}

Source: Authors own compilation. 


\subsection{Optimum leverage hypothesis}

Leverage hypothesis posits that companies are more likely to do repurchase if their actual debt equity ratio is less than the target ratio (Bagwell and Shoven, 1988; Dittmar, 2000; and Mitchell and Dharmawan, 2007). Titman et al. (2001) reported that the difference between the actual and target leverage ratio plays an important role in repurchase decision. The higher the difference between actual and optimal leverage ratio, the probability of repurchase is also more. So by undertaking share repurchase firms increase the proportion of leverage in the capital structure of the firm, as a result the overall cost of capital is reduced.Share repurchases make the underlevered firm get more tax shield and increase the value of the firm.

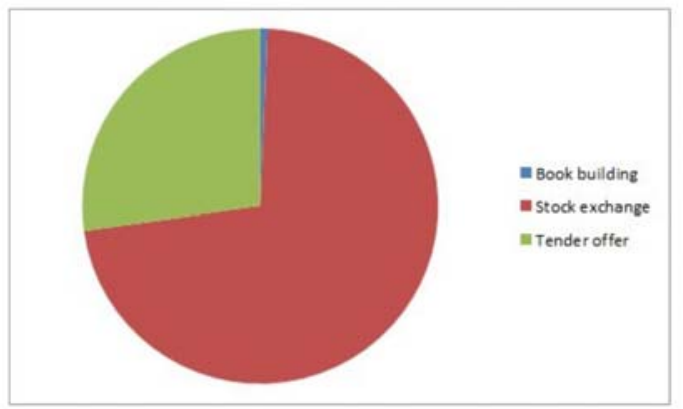

Source: Authors own compilation

Figure 1. Methods of Share Repurchase

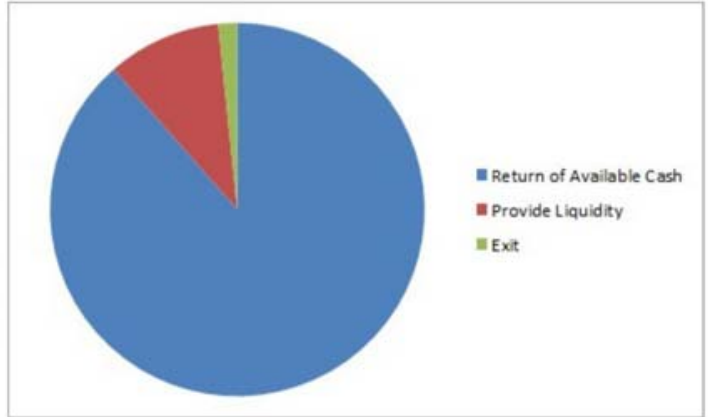

Figure 2. Reason of Share repurchases

\subsection{Stock option hypothesis}

Around 1950s, companies in USA started giving stock options to their senior executive as a part of compensation but later on, started giving these to all employees. When stock options are exercised by employees, outstanding shares of the companies increases resulting in EPS dilution. So to neutralise the effect of stock options on EPS, companies repurchase shares. Kahle (2002) reported that firms announce repurchase when executives have large stock options outstanding because dividend declaration will decrease the value of stock option. But the actual share repurchase depends on the total options exercisable by all the employee. Skinner et al. (2003) reported that companies increase repurchase to offset the dilutive effect of stock option.

\subsection{Takeover deterrence hypothesis}

Takeover hypothesis posit that companies use share repurchase as a defensive strategy to prevent hostile takeover. When there is a threat from the competitor, firms immediately increase their stake to prevent hostile takeover. Bagwell (1990) documented that company's face upward sloping supply curve at the time of repurchase in a Dutch auction tender offer. It means the shareholders who believe that the values of their shares are more than the repurchased price, don't tender their shares for sale. So the cost of non-selling shares will be more than the repurchased shares. Bagwell (1991) reported that under the condition of upward sloping supply curve, the takeover cost to the acquirer will be more if the target firm distribute 
cash through repurchase than dividend. Sinha (1991) documented that a debt-financed repurchase is a defence mechanism available with the target firm from being sold out to the acquirer. This transaction increases the value of the firm and makes it less attractive target. Debt-financed repurchase is a trade-off between the lower probability of takeover and financial distress cost.

\subsection{Substitution Hypothesis}

Substitution hypothesis means the preference for share buyback of shares as a payout method to shareholders over the dividend. In this case, companies finance their share buyback with the funds that can be otherwise used to increase the dividend. The main cause for substitution hypothesis is the taxable nature of income from dividend paid and share buyback in the hands of shareholders. The gain from share repurchase is taxed under either short term or long term capital gain at the hands of shareholder and dividend paid by the company is taxed as a regular income in the hands of shareholders. As capital gain tax is much lower than the dividend, share repurchase is more tax efficient and valuable to shareholders (Grullon and Michaely, 2000).The second important aspect of substitution is the timing and flexibility associated with share buyback. Unlike dividends, share repurchase does not promise cash flow in a regular interval (Dittmar, 2000).

Stephens et al. (2000) documented that firms having more volatile cash flow are likely to repurchase shares rather than increasing dividend. Firms with operating (Permanent) cash flow are more likely to increase dividend and firm with non-operating (Temporary) cash flow are more likely to repurchase shares. This study concludes that repurchase have not completely replaced dividend, but it is growing fast as an important form of payout method.

\subsection{Liquidity Hypothesis}

The relation of liquidity with repurchase is first propounded by Barclay and Smith (1988). They reported that repurchasereduces liquidity in the market. Brockman et al. (2008) reported for the first time the effect of liquidity on the repurchase. Before this, many studies examined the effect of repurchase on post-buyback liquidity of the stocks. This paper posited that liquidity has a direct impact on the repurchase of the firm and a residual effect on the dividend decisions of the firm. Repurchase initiating firms are more liquid than dividend initiating firms and the size of repurchase increases with liquidity. So liquidity may be a motivation for the firm to do repurchase.

\subsection{Corporate Governance Hypothesis}

Lee et al. (2007) documented that managers pose timing ability in the context of repurchase announcement. Managers have more information about the internal affair of the company than outsiders, so they can time the repurchase to get the advantage of undervaluation of shares. By the timing of repurchase, thefirm can repurchase their shares at a very less price. If the ownership of the firmis concentrated among insiders, then there is a probability of windfall gain of the insiders by timing the repurchase. So there should be a check on the repurchase decision of the firms. Rules regarding repurchase are different in the various countries. In India, if the firm wants to repurchase less than $10 \%$ of paid-up capital and free reserve then only 
board approval is necessary and above $10 \%$ it requires shareholders' approval. So the directors should be fair and justified enough at the time of approval of share repurchase. Yarram (2014) examined the relationship between the corporate governance variables and found a positive relationship between board independence and share repurchase decisions. Corporate governance parameters of a company may influence the share repurchase decision.

Table 4. Relationship of Hypotheses with Share Buyback Decision

\begin{tabular}{|l|c|}
\hline Hypothesis & Sign \\
\hline Signaling & + \\
\hline Excess capital & + \\
\hline Leverage & + \\
\hline Stock option & + \\
\hline Takeover Deterrence & + \\
\hline Substitution & + \\
\hline Liquidity & + \\
\hline Corporate governance & + \\
\hline
\end{tabular}

\section{Determinants of Share buyback}

Vafeas (1997) found that both agency cost and signaling play an important role inchoosing tender method over open market repurchase. An overinvestment firm backed by excess cash flow is more likely to choose tender offer than open market repurchase. Firm's choice in between tender offer and open market repurchase depends on short term or long term undervaluation of shares.

Dittmar (2000) examined the motivations behind share repurchase in the US by taking all the hypotheses simultaneously together viz. excess capital, undervaluation, optimal leverage, management incentive and takeover deterrence. The objective of the study is to find out the effect of all the hypotheses together without ignoring the effect of any single hypothesis. The study found that out of the above hypotheses undervaluation is the prime determinants for repurchase followed by excess capital hypothesis.

Jagannathan and Stephens (2003) examined motives of firms, behind infrequent, occasional and frequent repurchases. Frequentrepurchasers are large, less variation in operating income, more institutional ownership, and higher dividend pay-out ratio than infrequent repurchasers. In case of infrequent repurchasers, undervaluation is a primary motive for share buybacks, unlike frequent repuchasers. The marketfavors all repurchases, but market reaction to infrequent repurchase is stronger than other repurchases.

Backer et al. (2003) used survey method to examine the reasons of recent share buyback among US corporations. They tested five hypotheses i.e. signaling, agency cost of free cash flow, capital market allocations, tax-motivated substitutions for dividend and capital structure adjustments, and found that undervaluation is the most important motive behind repurchase followed by lack of investment opportunities.

Grullon and Michaely (2004) explored the economic motivations behind open market 
repurchase in the US. The findings of this study show that repurchasing firms reduce the current level of investment in capital expenditure and $R \& D$ to finance the repurchase program. This study found that that systematic risk and cost of capital of repurchasing firm declines after the announcement. The positive market reaction to the announcement is due to decrease in the free cash flow at management's disposal and systematic risk of the firm.

Mitchell and Dharmawan (2007) examined the substitution, undervaluation signaling, excess debt capacity and free cash flow hypotheses of repurchase in a standardized and transparent market, unlike the US. The study found that signaling of undervaluation and reduction of agency cost is the primary determinant of share buyback of share followed by excess debt capacity in the Australian market.

Li and McNally (2007) examined signalling, agency, undervaluation, optimal capital structure and dividend substitution hypotheses to identify the determinants of share repurchase decisions in Canada. The study found that firms with greater free cash flow, lower market to book ratio, negative return prior announcement and more insider holdings are more likely to repurchase. In Canada, firms are motivated to repurchase mainly by the agency hypothesis followed by undervaluation hypothesis.

Benhamouda and Watson (2010) examined the determinants influencing open market repurchase decisions in the UK. The study found that excess capital and substitution hypotheses are the motivating factors for share repurchase. This study doesn't support stock option hypothesis.

Farrugia et al. (2011) examined the relationship between the economic states and repurchase of shares by taking Australian data. This study shows that share repurchase programs are positive and statistically significant in high economic states compared to other states. They also reported that firms going for frequent repurchase enjoyed a stronger return all across the business cycle compared to the firms going for infrequent or occasional repurchase.

Lee and Suh (2011) examined the relationship between excess cash holding and the intention to repurchase shares by taking seven countries such as Australia, Germany, Japan, France, Canada, UK and the US. They established a positive relationship between large cash holdings and repurchase of shares and also found that excess cash arises out of reduction in capital expenditure. The findings of the paper support two hypotheses such as excess capital hypothesis and temporary cash flow hypothesis.

Andriosopoulos and Hoque (2013) reported that firm size, cash dividend, and ownership concentration have a significant impact on the repurchase decision of the firms in all these countries (UK, Germany and France). The results show that large and widely held firms are more likely to make share buyback announcement and also found a complementary relationship between dividend payment and share repurchase in UK and Germany.

Chung et al. (2013) explored signalling, free cash flow, management incentives, leverage, substitution and moral hazard hypotheses for determining factors influencing repurchase decision in Taiwan. The study found that out of the above hypotheses only signalling and free cash flow hypotheses play a significant role in influencing repurchase decisions. 
Bonaime et al. (2014) examined the determinants of share buyback of shares under the condition of target capital structure and equity that is mispriced. The study found that out of the four combinations of target capital structure and mispricing (Under levered/Undervalued, Under levered/Overvalued, Over-levered/undervalued, Over-levered/overvalued) the firms add more value when it is under levered and undervalued both. So this paper concluded that under levered and undervalued firms are more likely to announce repurchase than other firms.

Yarram (2014) examined various factors influencing open market repurchases in Australia. The study supports the agency, signaling, and leverage hypotheses and doesn't support excess cash flow and substitution hypotheses. The unique contribution of this study is, it blends corporate governance variables with other firm-specific parameters to examine the impact of corporate governance on repurchase decisions in Australia. The results show that board independence has a positive influence on repurchase decisions.

Table 5. Summary of empirical studies on determinants of share repurchase

\begin{tabular}{|c|c|c|c|}
\hline Author(s) \& Year & $\begin{array}{c}\text { Country \& Period } \\
\text { of Study }\end{array}$ & Method & Findings \\
\hline Dittmar(2000) & $\begin{array}{l}\text { USA } \\
(1977-1996)\end{array}$ & Tobit Model & $\begin{array}{l}\text { Undervaluation is the prime motive } \\
\text { for share repurchase followed by } \\
\text { excess capital. }\end{array}$ \\
\hline $\begin{array}{l}\text { Jagannathan and } \\
\text { Stephens (2003) }\end{array}$ & $\begin{array}{l}\text { USA } \\
(1986-1996)\end{array}$ & Logit Model & $\begin{array}{l}\text { Frequent repurchasersare } \\
\text { characterized by larger firm size, } \\
\text { less variation in operating income } \\
\text { than infrequent repurchasers. }\end{array}$ \\
\hline $\begin{array}{l}\mathrm{Li} \quad \& \quad \text { McNally } \\
(2007)\end{array}$ & $\begin{array}{l}\text { Canada } \\
(1987-2000)\end{array}$ & $\begin{array}{l}\text { conditional Even } \\
\text { Study }\end{array}$ & $\begin{array}{lll}\text { The repurchaseis motivated by } \\
\text { agency cost followed by } \\
\text { undervaluation hypothesis. }\end{array}$ \\
\hline $\begin{array}{l}\text { Mitchell and } \\
\text { Dharmawan } \\
(2007)\end{array}$ & $\begin{array}{l}\text { Australia } \\
(1996-2001)\end{array}$ & Logit Model & $\begin{array}{l}\text { The repurchaseis motivated by } \\
\text { signaling of undervaluation } \\
\text { followed by leverage hypothesis. }\end{array}$ \\
\hline $\begin{array}{l}\text { Andriosopoulos } \\
\text { and Hoque (2013) }\end{array}$ & $\begin{array}{l}\text { UK, Germany, and } \\
\text { France } \\
(1997-2006)\end{array}$ & Logit Model & $\begin{array}{l}\text { Excess cash flow hypothesis is the } \\
\text { prime motive for share repurchase in } \\
\text { all the three countries }\end{array}$ \\
\hline Yarram (2014) & $\begin{array}{l}\text { Australia } \\
(2004-2010)\end{array}$ & Probit Model & $\begin{array}{l}\text { The repurchaseis motivated by } \\
\text { signaling, leverage and agency cost } \\
\text { hypothesis. }\end{array}$ \\
\hline
\end{tabular}

Source: Compiled by authors from cited research articles.

\section{Share Repurchases and Liquidity}

Barclay and Smith (1988) reported for the first time that liquidity plays asignificant role in choosing between cash dividend and open market repurchase as a payout method to shareholders in the US. This study coined two new terms in the field of liquidity viz. competing market maker hypothesis and information asymmetry hypothesis. Competing market maker hypothesis states that repurchase enhances liquidity by creating a lower bound 
in the buyer side and narrowing bid-ask spread when the market is efficient. Information asymmetry hypothesis states that repurchasedecreases liquidity by increasing bid-ask spread if managers pose more inside information than outsiders. This study supported the information asymmetry hypothesis and rejected the other hypothesis. Repurchase widens the bid-ask spread, resulting a decrease in stock liquidity and increase the cost of capital to the firm and a reduction in total value of the firm. But there is no liquidity issue associated with the dividend, so companies prefer dividend over repurchase despite tax benefit attached to repurchase.

Singh k. et al. (1994) examined the proposition that bid-ask spread widens at the time of repurchase given by Barclay and Smith. This study has taken volume, relative volume, spread and percentage of spread to measure liquidity. This paper compared the above parameter between pre-announcement period and post-announcement period. The result of this study is not consistent with the proposition that liquidity decreases during repurchase activity. The finding of this paper is that the percentage increase in the spread occurred in the period preceding to the announcement and remains stable during repurchase period.

Wiggins B. (1994) extended the study of Barclay and Smith (1988) by taking 195 announcementsin the US. In this study spread and depth have been taken as proxies to measure liquidity. This study has taken a control group for comparison of spread and depth with the sample. This paper finds no evidence to support the information asymmetry hypothesis given by Barclay and Smith (1988).

Miller and McConnell (1995) reviewed the proposition provided by Barclay and Smith (1988) by taking 248(158 new repurchases and 90 ongoing repurchases) announcements in NYSE. This study found no evidence to support the information asymmetry hypothesis proposed by the earlier research. So it concludes that firms should not deter themselves from buying back shares in the fear that it widens the bid-ask spread and reduces liquidity in the market.

Franz et al. (1995) examined changes in spread around repurchase to know the liquidity of the stocks. The result shows that both spread and percentage of spread narrow but only change in the spread is significant. The change of spread is caused by a reduction in information asymmetry cost after the announcement.

Brockman \& Chung (2001) examined the relationship between repurchase and liquidity by taking absolute spread, relative spread, and total depth, bid depth and ask depth as proxy measures in Hong Kong. This study found that when managers enter the market as informed trader, then the bid-ask spread widens and depth falls significantly. But when managers disclose their activity on the following day of repurchase then the spread and depth come back to the pre-repurchase level. This study documented that out of the three components of bid-ask spread (Order processing cost, inventory cost, and adverse selection cost), adverse selection cost increases due to the presence of informed traders in the market. So it leads to widening the bid-ask spread and reduction in the depth of the market.

Ahn et al. (2001) examined the market maker hypothesis in the context of tender offers by taking 65 fixed tender offers listed on the NYSE or American StockExchange (AMEX). This 
study has taken quoted spread; percentage quoted spread, effective spread, effectivepercentage spread, trading volume, and depth to measure liquidity. The results of this study show that liquidity increases during the offer period and again reverse back to the pre-announcement period after expiration of the offer. So the increase in liquidity in the market is temporary in nature.

Cook et al. (2004) explored the relationship between repurchase and liquidity by taking 64 US listed firms those additionally disclose the repurchase data. This study found that repurchase contributes to market liquidity by narrowing the bid-ask spread. The bid-ask spread is comparedwith three benchmarks such as the period before the announcement, then the non-share repurchase day before the repurchase day (Lag day) and the non-repurchase day after the repurchase transaction (Lead day).

Ginglinger and Hamon (2007) examined the relationship between actual repurchase and their impact on liquidity in France by taking bid-ask spread as a proxy for liquidity. The study found that the spread on repurchase days are significantly more than the non-repurchase day. So the study lends its support to information asymmetry hypothesis.

Nayar et al. (2008) examined the effect of Dutch auction (DA), and Fixed price tender offer (FPTO) repurchase on liquidity in the US by taking spread and depth as a proxy for liquidity. The study reported that liquidity increases during the offer period and bounce back to the original pre-announcement period after expiration of the offer. The change in the liquidity is transitory in nature.

Ridder and Råsbrant (2009) examined the effect of repurchase on liquidity in Sweden. This study has taken absolute \& relative spread, total depth, bid depth and ask depth to measure liquidity. The study found that repurchases narrow down the bid-ask spread resulting increase in liquidity and also increase the depth of the market. This study finds a significant decrease in the bid-ask spread (3\%) from non-repurchase days to repurchase day.

McNally and Smith (2011) examined both price support and information asymmetry hypotheses to determine the impact of repurchase on liquidity in Canada. The results show that the spreads narrows and depth increase on repurchase days than non-repurchase days. The study also segregated the components of spreads and compared these cost (Adverse selection and inventory cost) to the non-repurchase days. This study finds no evidence that adverse selection cost increases due to repurchase, so it rejects the information asymmetry hypothesis.

CesariDe et al. (2011) examined two competing hypotheses,i.e., information asymmetry andcompeting market maker in Italy. The study found evidence to support the competing market maker hypothesis. It means repurchases enhance liquidity by a reducing in bid-ask spread.

\section{Share Repurchases and Earnings Management}

Bartov et al. (2002) reported that after controlling the overall earnings performance of the quarter, firms those can match the analysts' expectations earn 3\% more than their peer who 
failed to do so. To save the firms from great economic loss, managers always try to achieve the earnings expected by analyst. But when the actual earning is not enough to meet or beat analyst forecast, then manager take help of earnings management to achieve the target. Earning management is an accounting strategy used by the management to achieve the twin objectives of the firm's (Income smoothing and meeting or beating analysts). Managers can manipulate the reported financial statement because of certain assumptions followed in accounting practices. Due to these assumptions, managers get a scope for using their discretion or judgment while reporting accounting figures to external stakeholders. More specifically, this type of earnings management is an activity where managers use their discretion to mislead stakeholders about the economic performance of the company to influence contractual outcomes (Healy and Walhen, 1999). There are two types of earnings management viz. accrual-based earnings management (AM) and real earnings management (RM).Changing methods of depreciation of fixed assets and changing the provisions of doubtful debts are two examples of AM. In contrast, RM is accomplished by changing the firm's underlying operations (Roychowdhury, 2006). Examples of RM include cutting prices towards the end of the year for increasing sales, delaying desirable investment, and selling fixed assets to affect gain and loss so as to influence current period earnings.

Table 6. Summary of empirical studies on liquidity after share repurchase

\begin{tabular}{|l|l|l|l|}
\hline \multicolumn{1}{|c|}{ Author(s) \& Year } & \multicolumn{1}{|c|}{$\begin{array}{c}\text { Country \& } \\
\text { Period of Study }\end{array}$} & \multicolumn{1}{c|}{ Froxies } \\
\hline Barclay and Smith(1988) & USA (1970-78) & Bid-ask spread & $\begin{array}{l}\text { Support information asymmetry hypothesis, } \\
\text { liquidity decreases after share buybacks }\end{array}$ \\
\hline Wiggins B (1994) & USA (1988-90) & Bid-ask spread & $\begin{array}{l}\text { Bid -ask spread decreases and no significant } \\
\text { change in depth during repurchase. }\end{array}$ \\
\hline Cook et al. (2004) & & Depth & Liquidity increases due to share repurchase. \\
\hline & USA (1993-94) & Spread & Price impact \\
\hline Ginglinger and Hamon (2007) & France (2000-02) & Bid-ask spread & Liquidity decreases due to share repurchase. \\
\hline Ridder and Råsbrant (2009) & Sweden (2002-05) & Absolute spread & Liquidity increases due to share repurchase. \\
\hline & & Relative spread & \\
\hline & & Total depth & \\
\hline CesariDe et al.(2012) & USA (2004-06) & Amihud illiquidity ratio & Firms are likely to purchase when liquidity is high. \\
\hline
\end{tabular}

Source: Compiled by authors from cited research articles.

Managers do earning management for three broad reasons: (1) when executive compensation is associated with the earnings. (2) Public traded companies are under constant pressure to meet or beat the analysts earning forecast. (3) Before any corporate activities such as initial public offering (IPO), seasoned equity offering (SEO), merger and repurchase. Prior research on earnings management has found evidence of earning manipulation around different corporate activities. Perry and Williams (1994) reported earning management before 
management buyouts and Teoh, Welch, and Wong (1998a) reported that managers inflate earning before IPO to sell their shares at a higher price. Shivkumar (2000), Teoh, Welch, and Wong (1998b) reported that managers inflate earning before SEO to sell their shares at a higher price, and Erickson and Wang (1999) reported that acquiring firms overstate earnings before stock for stock merger. Above studies examine two hypotheses around corporate events such as managerial opportunism and market response. Managerial opportunism states that managers have incentives to deflate (inflate) their earnings before the corporate event. Market response hypothesis states that managers do earnings management because the market expects them to do so. Though there are a large number of studies on earnings management around different corporate activity, thereare very few studies on earnings management around repurchase.

Vafeaset al. (2003) examined the relationship between earnings management and tender offer of repurchase by considering discretionary accrual as a proxy. This study tested the managerial opportunism hypothesis around repurchase. According to this hypothesis, companies deflate their earnings before repurchase to attract shareholders to sell their shares at a low price. In this case, non-tendering shareholders gain at the cost of tendering shareholders. But the study found a weak evidence of earnings management before tender repurchase in the US.

Rodriguez and Yue (2005) examined earnings management around open market share repurchases. This study tested two hypotheses relating to earnings management viz. managerial opportunism and market response. Managerial opportunism hypothesis states that managers are motivated to deflate their earning before repurchase to buy the shares at a low price. Market response hypothesis assumes that market is efficient, and investors get to know about the earnings management by the firm after the announcement. The study found that discretionary accruals are significantly negative in the year before repurchase, which is consistent with both the hypotheses. The results of the studyshow that firms those aggressively deflate their earnings earn $28 \%$ more return than control firms. The study also examined the relationship between manager's ownership and reporting behavior of firms and found that more the stake of manager in the firm the higher degree of negative earnings management.

Louis and White (2007) examined the relationship between pre-repurchase reporting behavior (Fixed tender offer and Dutch auction fixed tender offer) and the motive behind repurchase. It posits that firms undertaking share buyback for signaling are not likely to deflate their earnings before repurchase. This study finds significant negative discretionary accruals before Dutch auction tender offer than the Fixed tender offer. It concludes that fixed price tender offer gives a strong signal of undervaluation than Dutch auction fixed tender offer.

Gong et al. (2008) examined the relationship among post-repurchase operating performance, abnormal stock return and earnings management before repurchase announcement. This study has taken abnormal accruals as a proxy for earnings management. The study found that firms deflate their earning if repurchase announcement is followed by actual repurchase in the announcement quarter or the next quarter. The study finds no evidence of negative abnormal 
accruals for firms, only announcing repurchase without any intention of actual repurchase. The finding of the study shows a negative relationship between abnormal accruals and improvement in post operating performance and abnormal stock return. The study also reported that if the earnings management effects are wiped out, then there is no significant increase in post operating performance and abnormal stock return. So it proves that increase in operating performance and abnormal stock return after repurchase is partly explained by earnings management.

Ikenberry et al. (2010) examined managerial intention behind repurchase announcement by taking discretionary accruals as a proxy because of the failure of traditional proxies (Program size and post completion rate) to explain the motives behind repurchase. The study found that the managers of firms with poor earning quality reported high positive discretionary accrual before repurchase announcement to boost the stock price due to either their incentives are linked to the value of the firms or stock options held by the executives. But in the long run,high discretionary accrual firms underperform other non-high accrual firms.

Huang and Chen (2013) examined the effect of Sarbanes-Oxley Act (SOX) on earnings management by the firms before the announcement of open market repurchases. This piece of legislation was passed in 2002 to improve the quality of the reported financial information after multiple scams in the US to keep the investor's confidence intact. The act increased the role of independent director in the board and required that all members of an audit committee should be independent directors in a public company. This study found that managers of open market repurchases are less likely to deflate their earnings before repurchasing after the passage of SOX due to the stringent regulations.

Di and Marciukaityte (2015) examined the cause behind earning management around share repurchases in the form of two hypotheses viz. managerial opportunism and income smoothing. The objective of managerial opportunism hypothesis is to mislead the investors by deflating income before repurchase. The purpose of income smoothing hypothesis is to reduce volatility in the reported income due to a sudden increase or decrease in revenue. It also reduces information asymmetry and improves informativeness of earnings. The study found a negative relationship between discretionary current accruals and contemporaneous cash flow and give its support for income smoothing. This study provides an alternative explanation behind negative pre-repurchase discretionary accruals. 
Table 7. Summary of empirical studies on earnings management around share repurchase

\begin{tabular}{|l|l|l|l|}
\hline \multicolumn{1}{|c|}{ Author(s) \& Year } & $\begin{array}{c}\text { Country \& } \\
\text { Period of } \\
\text { Study }\end{array}$ & \multicolumn{1}{|c|}{ Proxies } & \multicolumn{1}{|c|}{ Findings } \\
\hline Vafeas et al. (2003) & $\begin{array}{l}\text { USA } \\
(1984-89)\end{array}$ & Discretionary accruals & Managers deflate earnings before repurchase. \\
\hline Rodriguez and Yue (2005) & $\begin{array}{l}\text { USA } \\
(1980-98)\end{array}$ & Discretionary accruals & $\begin{array}{l}\text { Discretionary accruals are significantly } \\
\text { negative before repurchase. }\end{array}$ \\
\hline Louis and White (2007) & $\begin{array}{l}\text { USA } \\
(1981-01)\end{array}$ & Discretionary accruals & $\begin{array}{l}\text { Firms never deflate their earnings if they want } \\
\text { to give signals }\end{array}$ \\
\hline Gong et al.(2008) & $\begin{array}{l}\text { USA } \\
(1984-02)\end{array}$ & Abnormal Accruals & $\begin{array}{l}\text { Significant negative abnormal accruals } \\
\text { around share repurchase. }\end{array}$ \\
\hline Ikenberry et al. (2010) & USA (1980-00) & Discretionary abnormal accruals & $\begin{array}{l}\text { Managers reported high positive } \\
\text { discretionary accrual to boost the stock price } \\
\text { to mislead the investors. }\end{array}$ \\
\hline
\end{tabular}

Source: Compiled by authors from cited research articles.

\section{Conclusion}

Share repurchase as a pay-out method first started in the USA during 1950.Since then, research has been going on this area in determining the various reason for share repurchase, the value of firms after share repurchase, the timing of repurchase and the impact on stock price and return after the announcement of repurchase. This study only analysed the literature relating to factors influencing share repurchase, the impact of repurchase on the liquidity of the stock and earnings management around share repurchase. The factors those drive repurchase decisions may differ from country to country depending on the institutional framework of share buyback in the particular country. For this reason, in a differentcountry, different hypothesis are influencing share buyback decisions. The impact of share repurchase on liquidity is also distinctin the various countries. In some country, liquidity increases after repurchase and vice-versa in other countries. Managers deflate earnings in the previous year of repurchase to entice shareholder to sell their shares.

In this process, non-selling shareholders or long-term shareholders gain at the cost of short-term shareholders. The level of earnings management depends on upon the country's audit quality and corporate governance. The study also gives a close and brief view of the Indian rules and regulations those monitor share buybacks by Indian companies. All the amendments in the SEBI regulations and the changes in new Companies Act 2013 from the old Companies Act 1956, is also illustrated in the paper.

The extensive review of literature opens the future scope of study in this area. To find out the motivation or determinant of share repurchase, different firm-specific parameters have been taken by various researchers. In developing countries or emerging economy where share repurchase started in the last decade of $20^{\text {th }}$ century, the only handful of research has been carried out in this area. Due to the market transparency and difference in the regulatory framework, the well documented common determinants for share buyback may not be valid 
in emerging market economies. So it is examined on country wise, and the findings are different than developed countries. In emerging markets, the complex relationship among share buyback announcement, stock return, and the premium paid on share buyback and value of the firm has not been tested in a wider way. Similarly, ownership structure and its impact on repurchase decision and implication of liquidity on share repurchase or impact of repurchase on stock market liquidity and the relationship between dividend payment and share buybacks need to be explored in emerging market economies.

\section{Acknowledgement}

The research is financed by University Grant Commission, Government of India.

\section{References}

Ahn, H. J., Cao, C., \& Choe, H. (2001). Share repurchase tender offers and bid-ask spreads. Journal of banking \& finance, 25(3), 445-478. http://dx.doi.org/10.1016/S0378-4266(00)00084-4

Andriosopoulos, D., \& Hoque, H. (2013). The determinants of share repurchase in Europe. International Review of Financial Analysis, 27, 65-76. http://dx.doi.org/10.1016/j.irfa.2012.12.003

Arora, A., \&Pasricha, J. S. (2012, December). Motivations for Buyback among Indian Companies. In XI Capital Markets Conference (pp. 21-22).

Arora, Ashish. (2012). Liquidity Effects of Buyback Announcements: Evidence for Indian Capital Markets. Apeejay Journal of Management \& Technology, 7(1).

Bagwell, L. S. (1991). Share repurchase and takeover deterrence. The RAND Journal of Economics, 72-88. http://dx.doi.org/10.2307/2601008

Bagwell, L. S. (1992). Dutch auction repurchases An analysis of shareholder heterogeneity. The Journal of Finance, 47(1), 71-105. http://dx.doi.org/10.1111/j.1540-6261.1992.tb03979.x

Bagwell, L. S., \& Shoven, J. B. (1988). Share repurchases and acquisitions: An analysis of which firms participate. In Corporate takeovers: Causes and consequences (pp. 191-220). University of Chicago Press.

Baker, H. K., Powell, G. E., \& Veit, E. T. (2003). Why companies use open-market repurchases: A managerial perspective. The Quarterly Review of Economics and Finance, 43(3), 483-504. http://dx.doi.org/10.1016/S1062-9769(02)00151-5

Barclay, M. J., \& Smith, C. W. (1988). Corporate payout policy: Cash dividends versus open-market repurchase. Journal of Financial Economics, 22(1), 61-82. http://dx.doi.org/10.1016/0304-405X(88)90022-0

Bartov, E. (1991). Open-market stock repurchases as signals for earnings and risk changes. Journal of Accounting and Economics, 14(3), 275-294. http://dx.doi.org/10.1016/0165-4101(91)90015-G 
Bartov, E., Givoly, D., \& Hayn, C. (2002). The rewards to meeting or beating earnings expectations. Journal of Accounting and Economics, 33(2), 173-204. http://dx.doi.org/10.1016/S0165-4101(02)00045-9

Benhamouda, Z., \& Watson, R. (2010). A research note on the determinants of UK corporate share repurchases decisions. Applied Financial Economics, 20(7), 529-541. http://dx.doi.org/10.1080/09603100903459857

Bens, D. A., Nagar, V., Skinner, D. J., \& Wong, M. F. (2003). Employee stock options, EPS dilution, and stock repurchases. Journal of Accounting and Economics, 36(1), 51-90. http://dx.doi.org/10.1016/j.jacceco.2003.10.006

Bhattacharya, S. (1979). An exploration of nondissipative dividend-signaling structures. Journal of Financial and Quantitative Analysis, 14(04), 667-668. http://dx.doi.org/10.2307/2330441

Bonaimé, A. A., Öztekin, Ö. \& Warr, R. S. (2014). Capital structure, equity mispricing, and stock repurchases. Journal of Corporate Finance, 26, 182-200. http://dx.doi.org/10.1016/j.jcorpfin.2014.03.007

Boudry, W. I., Kallberg, J. G., \& Liu, C. H. (2013). Investment opportunities and share repurchases. Journal of Corporate Finance, 23, 23-38. http://dx.doi.org/10.1016/j.jcorpfin.2013.07.006

Brockman, P., Howe, J. S., \& Mortal, S. (2008). Stock market liquidity and the decision to repurchase. Journal of Corporate Finance, 14(4), 446-459. http://dx.doi.org/10.1016/j.jcorpfin.2008.06.001

Brockman, P., \& Chung, D. Y. (2001). Managerial timing and corporate liquidity: evidence from actual share repurchases. Journal of Financial Economics, 61(3), 417-448. http://dx.doi.org/10.1016/S0304-405X(01)00068-X

Chan, K., Ikenberry, D. L., Lee, I., \& Wang, Y. (2010). Share repurchases as a potential tool to mislead investors. Journal of Corporate Finance, 16(2), 137-158. http://dx.doi.org/10.1016/j.jcorpfin.2009.10.003

Chan, K., Ikenberry, D. L., \& Lee, I. (2007). Do managers time the market? Evidence from open-market share repurchases. Journal of Banking \& Finance, 31(9), 2673-2694. http://dx.doi.org/10.1016/j.jbankfin.2006.09.017

Chavali, Kavita, and S. Shemeem. (2011). Impact of Buybacks on Share Price Performance of Companies in Indian Context. European Journal of Finance and Banking Research, 4(4), 23.

Chen, S. S., \& Huang, C. W. (2013). The Sarbanes-Oxley Act, Earnings Management, and Post-Buyback Performance of Open-Market Repurchasing Firms. Journal of Financial and Quantitative Analysis, 48(06), 1847-1876. http://dx.doi.org/10.1017/S0022109014000040 
Comment, R., \& Jarrell, G. A. (1991). The relative signaling power of Dutch-auction and fixed-price self-tender offers and open-market share repurchases. The Journal of Finance, 46(4), 1243-1271. http://dx.doi.org/10.1111/j.1540-6261.1991.tb04617.x

Cook, D. O., Krigman, L., \& Leach, J. C. (2004). On the timing and execution of open market repurchases. Review of Financial Studies, 17(2), 463-498. http://dx.doi.org/10.1093/rfs/hhg028

De Cesari, A., Espenlaub, S., \& Khurshed, A. (2011). Stock repurchases and treasury share sales: Do they stabilize price and enhance liquidity? Journal of corporate finance, 17(5), 1558-1579. http://dx.doi.org/10.1016/j.jcorpfin.2011.08.002

De Ridder, A., \& Råsbrant, J. (2009). The market liquidity impact of repurchase is trading. Nasdaq OMX website.

Di, H., \& Marciukaityte, D. (2015). Earnings are smoothing around open-market share repurchases. Review of Accounting and Finance, 14(1). http://dx.doi.org/10.1108/RAF-10-2012-0111

Dittmar, A. K. (2000). Why Do Firms Repurchase Stock*? The Journal of Business, 73(3), 331-355. http://dx.doi.org/10.1086/209646

Dua, Vibha, HimanshuPuri, \& R. K. Mittal. (2010). Impact of buy-back of shares on stock prices in India: An empirical testing of stock market efficiency in its semi-strong form. Pranjana: The Journal of Management Awareness, 13(1).

Erickson, M., \& Wang, S. W. (1999). Earnings management by acquiring firms in stock for stock mergers. Journal of Accounting and Economics, 27(2), 149-176. http://dx.doi.org/10.1016/S0165-4101(99)00008-7

Franz, D. R., Rao, R. P., \& Triparty, N. (1995).Informed trading risk and bid-ask spread changes around open market stock repurchases in the NASDAQ market. Journal of Financial Research, 18(3), 311-327. http://dx.doi.org/10.1111/j.1475-6803.1995.tb00569.x

Farrugia, D., Graham, M., \& Yawson, A. (2011). Economic conditions and the motives for multiple open-market share buybacks. Research in International Business and Finance, 25(2), 156-168. http://dx.doi.org/10.1016/j.ribaf.2011.01.003

Ginglinger, E., \& Hamon, J. (2007). Actual share repurchases timing and liquidity. Journal of banking \& finance, 31(3), 915-938. http://dx.doi.org/10.1016/j.jbankfin.2006.07.006

Gong, G., Louis, H., \& Sun, A. X. (2008). Earnings Management and Firm Performance Following Open-Market Repurchases. The Journal of Finance, 63(2), 947-986. http://dx.doi.org/10.1111/j.1540-6261.2008.01336.x

Grullon, G., \&Michaely, R. (2002).. "Dividends, share repurchases, and the substitution hypothesis." the Journal of Finance 57.4 (2002): 1649-1684. 
Grullon, G., \& Michaely, R. (2004). The information content of share repurchases programs. The Journal of Finance, 59(2), 651-680. http://dx.doi.org/10.1111/j.1540-6261.2004.00645.x

Haw, I. M., Ho, S. S., Hu, B., \& Zhang, X. (2013). Legal Institutions, Ownership Concentration, and Stock Repurchases Around the World: Signal Mimicking? The International Journal of Accounting, 48(4), 427-458. http://dx.doi.org/10.1016/j.intacc.2013.10.002

Healy, P. M., \&Wahlen, J. M. (1999). A review of the earnings management literature and its implications for standard setting. Accounting horizons, 13(4), 365-383. http://dx.doi.org/10.2308/acch.1999.13.4.365

Hovakimian, A., Opler, T., \& Titman, S. (2001). The debt-equity choice. Journal of Financial and Quantitative analysis, 36(01), 1-24. http://dx.doi.org/10.2307/2676195

Hyderabad, R. L. (2013). An Examination of Free Cash Flow Hypothesis in Indian Repurchase Decisions. Asian Journal of Business Management, 5(1), 1-12.

Hyderabad, R. L. (2013). Are share repurchases substitutes for dividend payment in India? The IUP Journal of Applied Finance, 19(1), 27-46.

Jagannathan, M., Stephens, C. P., \& Weisbach, M. S. (2000). Financial flexibility and the choice between dividends and stock repurchases. Journal of financial Economics, 57(3), 355-384. http://dx.doi.org/10.1016/S0304-405X(00)00061-1

Jagannathan, M., \& Stephens, C. (2003). Motives for multiple open-market repurchase programs. Financial Management, 71-91. http://dx.doi.org/10.2307/3666337

Jensen, M. C. (1986). Agency cost of free cash flow, corporate finance, and takeovers. Corporate Finance and Takeovers. American Economic Review, 76(2).

Kahle, K. M. (2002). When a buyback isn'ta buyback: open market repurchases and employee options. Journal of Financial Economics, 63(2), 235-261. http://dx.doi.org/10.1016/S0304-405X(01)00095-2

Khaledi, N. (2013). Determinants of Firms Managing EPS through Share Repurchases. Academy of Accounting and Financial Studies Journal, 17(4), 83.

Lee, B. S., \&Suh, J. (2011). Cash holdings and share repurchases: International evidence. Journal of Corporate Finance, 17(5), 1306-1329. http://dx.doi.org/10.1016/j.jcorpfin.2011.06.006

Li, K., \& McNally, W. (2007). The information content of Canadian open market repurchases announcements. Managerial $\quad$ Finance, $\quad 33(1), \quad 65-80$. http://dx.doi.org/10.1108/03074350710715818

Liang, W. L. (2012). The information content of repurchase signals: Tangible or intangible information? Journal of Banking \& Finance, 36(1), 261-274. http://dx.doi.org/10.1016/j.jbankfin.2011.07.004 
Louis, H., \& White, H. (2007). Do managers intentionally use repurchase tender offers to signal private information? Evidence from firm financial reporting behavior. Journal of Financial Economics, 85(1), 205-233. http://dx.doi.org/10.1016/j.jfineco.2006.08.003

McNally, W. J., \& Smith, B. F. (2011). A microstructure analysis of the liquidity impact of open market repurchases. Journal of Financial Research, 34(3), 481-501. http://dx.doi.org/10.1111/j.1475-6803.2011.01299.x

Miller, J. M., \& McConnell, J. J. (1995). Open-market share repurchase programs and bid-ask spreads on the NYSE: Implications for corporate payout policy. Journal of Financial and Quantitative analysis, 30(03), 365-382. http://dx.doi.org/10.2307/2331346

Mitchell, J. D., \& Dharmawan, G. V. (2007). Incentives for on-market buy-backs: Evidence from a transparent buy-back regime. Journal of Corporate Finance, 13(1), 146-169. http://dx.doi.org/10.1016/j.jcorpfin.2006.12.002

Miller, Merton H., \& Franco Modigliani. (1961). "Dividend policy, growth, and the valuation of shares." the Journal of Business, 34(4), 411-433.

Nayar, N., Singh, A. K., \& Zebedee, A. A. (2008). Shares repurchase offers and liquidity: An examination of temporary and permanent effects. Financial Management, 37(2), 251-270. http://dx.doi.org/10.1111/j.1755-053X.2008.00012.x

Perry, S. E., \& Williams, T. H. (1994). Earnings management preceding management buyout offers. Journal of Accounting and Economics, 18(2), 157-179. http://dx.doi.org/10.1016/0165-4101(94)00362-9

Rajagopalan, N. V. R., \& Shankar, H. (2013). Buyback Announcements and Stock Market Reaction in India: Testing the Market Condition Hypothesis. IUP Journal of Applied Finance, 19(2), 64.

Rajagopalan, N. V. R., \& H. Shankar. (2012). Stock Market Behaviour Around Buyback Announcements in India: An Empirical Justification for Preferring the Open Market Repurchase Mode. Indian Journal of Finance, 6(12), 43-52.

Reddy, K. S., Nangia, V. K., \& Agrawal, R. (2013). Share repurchases, signalling effect and implications for corporate governance: Evidence from India. Asia-Pacific Journal of Management Research and Innovation, 9(1), 107-124.

Reddy Yarram, S. (2014). Factors influencing on-market share repurchase decisions in Australia. Studies in Economics and Finance, 31(3), 255-271. http://dx.doi.org/10.1108/SEF-02-2013-0021

Rodriguez, A., \& Yue, H. (2005). Open Market Share Repurchases and Earnings Management. Available at SSRN 2342273. http://dx.doi.org/10.2139/ssrn.2342273

Ross, S. A. (1977).The determination of financial structure: the incentive signaling approach. The bell journal of economics, 23-40. http://dx.doi.org/10.2307/3003485 
Roychowdhury, S. (2006). Earnings management through real activities manipulation. Journal of accounting and economics, 42(3), 335-370. http://dx.doi.org/10.1016/j.jacceco.2006.01.002

Securities and Exchange Board of India (Buy-back of securities) regulations. (1998).

Securities and Exchange Board of India (Buy-Back of Securities) (Amendment) Regulations. (1999).

Securities and Exchange Board of India (Buy-Back of Securities) (Amendment) Regulations, (2001).

Securities and Exchange Board of India (Buy-Back of Securities) (Amendment) Regulations, (2004).

Securities and Exchange Board of India (Buy-Back of Securities) (Amendment) Regulations, (2006).

Securities and Exchange Board of India (Buy-Back of Securities) (Amendment) Regulations, (2007).

Securities and Exchange Board of India (Payment of Fees) (Amendment) Regulations, (2008).

Securities and Exchange Board of India (Buy-back of securities) (Amendment) Regulations, (2012).

Securities and Exchange Board of India (Buy-back of securities) (Amendment) Regulations, (2013).

Securities and Exchange Board of India (Buy-back of securities) (Amendment) Regulations, (2015).

Shivakumar, L. (2000). Do firms mislead investors by overstating earnings before seasoned equity offerings?. Journal of Accounting and Economics, 29(3), 339-371. http://dx.doi.org/10.1016/S0165-4101(00)00026-4

Singh, A. K., Zaman, M. A., \&Krishnamurti, C. (1994). Liquidity changes associated with open market repurchase. Financial Management, 47-55. http://dx.doi.org/10.2307/3666055

Sinha, S. (1991). Share repurchase as a takeover defense. Journal of Financial and Quantitative Analysis, 26(02), 233-244. http://dx.doi.org/10.2307/2331267

Skinner, D. J. (2008). The evolving relation between earnings, dividends, and stock repurchases. Journal of Financial Economics, 87(3), $\quad$ 582-609. http://dx.doi.org/10.1016/j.jfineco.2007.05.003

Spence, M. (1973). Job market signaling. The quarterlyjournal of Economics, 355-374. http://dx.doi.org/10.2307/1882010 


\section{Macrothink}

Asian Journal of Finance \& Accounting

ISSN 1946-052X

Stephens, C. P., \& Weisbach, M. S. (1998). Actual share reacquisitions in open-market repurchase programs. The Journal of Finance, 53(1), 313-333. http://dx.doi.org/10.1111/0022-1082.115194

Teoh, S. H., Welch, I., \& Wong, T. J. (1998). Earnings management and the underperformance of seasoned equity offerings. Journal of Financial economics, 50(1), 63-99. http://dx.doi.org/10.1016/S03304-405X(98)00032-4

Teoh, S. H., Welch, I., \& Wong, T. J. (1998). Earnings management and the long-run market performance of initial public offerings. The Journal of Finance, 53(6), 1935-1974. http://dx.doi.org/10.1111/0022-1082.00079

The Companies Act 2013, Chapter 18, Ministry of law and justice, Government of India.

The Companies Act 1956, Ministry of law and justice, Government of India.

Vafeas, N. (1997). Determinants of the choice between alternative shares repurchase methods. Journal of Accounting, Auditing \& Finance, 12(2), 101-124.

Vafeas, N., \& Joy, O. M. (1995). Open market share repurchases and the free cash flow hypothesis G35. Economics letters, 48(3), 405-410. http://dx.doi.org/10.1016/0165-1765(94)00631-B

Vafeas, N., Vlittis, A., Katranis, P., \&Ockree, K. (2003). Earnings management around share repurchases: A note. Abacus, 39(2), 262-272. http://dx.doi.org/10.1111/1467-6281.00130

Vermelen, T. (1981). Common Stock Repurchase and Market Signaling. Journal of Financial Economic, 9, 139-183. http://dx.doi.org/10.1016/0304-405X(81)90011-8

Wiggins, J. B. (1994). Open market stock repurchases programs and liquidity. Journal of Financial Research, 17(2), 217-229. http://dx.doi.org/10.1111/j.1475-6803.1994.tb00187.x

Yeh, H. T., Huang, Y. X., \& Chung, K. C. (2013). An empirical study on influential determinants for enterprise capital reduction: Evidence from cash reduction and stock repurchase. The International Journal of Organizational Innovation, 100-114. 